\title{
Reconstruction of Congenital Aural Malformation
}

\author{
Jeong-Hoon $\mathrm{Oh}$ \\ Department of Otorhinolaryngology-Head and Neck Surgery, The Catholic University of Korea College of Medicine, Seoul, Korea
}

\section{선천성 외이 기형의 재건}

\author{
오 정 훈 \\ 가톨릭대학교 의과대학 이비인후과학교실
}

\author{
Received March 14, 2016 \\ Revised May 21, 2016 \\ Accepted May 23, 2016 \\ Address for correspondence \\ Jeong-Hoon Oh, MD, PhD \\ Department of Otorhinolaryngology- \\ Head and Neck Surgery, \\ The Catholic University of Korea \\ College of Medicine, \\ 180 Wangsan-ro, Dongdaemun-gu, \\ Seoul 02559, Korea \\ Tel +82-2-958-2148 \\ Fax $+82-2-960-4568$ \\ E-mail ojhent@catholic.ac.kr
}

The complexity of the auricle makes its reconstruction technically difficult, owing to the convexities and concavities of the underlying cartilage with its tightly adherent and thin overlying skin. This article gives an overview of the current practice in the field of auricular reconstruction. The majority of surgeons who perform auricular reconstruction continues to employ the well-established techniques developed by Brent and Nagata. Surgery takes between two and four stages, with the initial stage being construction of a framework of autogenous rib cartilage which is implanted into a subcutaneous pocket. Several modifications of these techniques have been reported. Understanding the various treatment options and having sufficient practice to increase the surgeon's skills are crucial to providing the patients with the best outcomes possible.

Korean J Otorhinolaryngol-Head Neck Surg 2016;59(6):419-23

\section{서 론}

외이의 3차원적 형태와 구조는 신체의 다른 부위와 비교할 때 매우 복잡하고 독특한 특징을 가지고 있다. 이개 연골은 형태적으로도 매우 복잡할 뿐만 아니라 이개 연골 특유의 탄성은 기술적으로도 이를 재현하는 것이 대단히 어려울 수 밖에 없다. 인체에서 복잡한 형태를 유지하면서 동시에 강한 탄성을 가지고 있고, 사방을 둘러싼 피부의 압축력을 견뎌내 는 이개 골조를 재건해내는 것은 매우 도전적인 시도로서, 현 재 가장 보편적으로 이용되는 보형물인 자가 늑연골은 면역 거 부반응이나 감염의 위험을 피할 수 있는 자가 연골조직 중에 서 필요한 크기를 얻을 수 있는 유일한 부위로 인식되고 있다. ${ }^{1)}$ 외이의 선천성 기형에 대한 분류는 여러 연구자에 의해 여 러 가지 관점에서 시도되어 왔으나 아직도 통일된 분류법이 없다. 대개는 소이증을 기준으로 Marx의 분류를 가장 널리 이용하지만, ${ }^{2)}$ 치료적 관점에서 본 Weerda와 Siegert의 분류 에 의하면 1 단계는 이개 재건을 위해 추가적인 피부이식 또는 연골조직이 필요하지 않은 경우를 말하며, 재건을 위해 피부
나 연골조직이 일부 필요한 경우를 2단계, 그리고 전체 재건 을 위해 피부 및 연골조직의 이식이 광범위하게 필요한 경우 를 3단계로 분류하여 치료 계획에 도움이 되도록 하였다. ${ }^{23)}$ 이 러한 분류는 다양한 정도의 외이 기형에 대한 수술 계획을 세우는 데 있어서 하나의 기준이 될 수 있으며, 실제로 외래에 서 비교적 흔히 접하는 경도 기형인 돌출귀(protruding ear)나 lop ear의 경우 추가적인 연골조직 또는 피부 피판 등이 필요 하지 않기 때문에 2 3단계의 외이 기형에 비해 술 전 계획 및 동의과정을 단순화할 수 있다. 하지만 같은 외이의 경도 기형 이라 할 수 있는 매몰귀(cryptotia)나 수축귀(constricted ear) 와 같은 경우 시각적으로 소실된 이개 구조가 많지 않더라도 막상 수술 시 기존 연골의 양과 형태가 매우 불완전하여 추가 적인 연골조직이나 피부 피판의 사용이 필요한 경우가 대부 분이므로 단순히 3 단계의 분류만으로 치료 계획을 단순화하 는 것은 쉽지 않다. 따라서 환아가 외래에 내원하였을 때 면 밀한 이학적 검사와 함께 정확한 사진 자료를 확보하고 이를 반복적으로 검토하여 적절한 술기를 계획하는 것이 좋은 수 술 결과를 얻기 위해 필요하다. 2 단계 이상의 기형이 있어서 추 
가적인 연골조직을 채취하게 되는 경우 이갑개 연골이나 비중 격 연골 등을 이용해서 부분적인 보강을 시도하는 경우도 있 지만, 이개의 3 차원 구조를 재건하기 위해 기본적으로 사용되 는 연골 공여부는 늑연골이다. 본 원고에서는 늑연골을 이용 한 외이 기형의 교정에 있어서 알아두어야 할 사항들에 대해 몇 가지 이야기하고자 한다.

\section{수술 시 고려하여야 할 사항}

소이증을 비롯한 외이 기형의 치료 계획에 있어 매우 중요 한 요소로서 수술의 시기가 있다. 소이증이 있는 경우 외이도 협착이 동반되는 경우가 많아서 외이도 재건술의 시기를 함 께 고려하여야만 하며, 또한 공여부 늑연골 부위의 손상과 이개의 성장이 완료되는 시기에 대한 고찰 역시 중요하다. ${ }^{4-6)}$ 수술의 적정 시기에 대해서는 다양한 의견이 존재하는데, 6 세경에 수술을 하는 것이 적절하다는 의견은 5 6세경에 이 미 성인 귀의 $90 \%$ 까지 성장이 이루어진다는 사실에 기인하며, 이 연령에서 외이 재건술을 시행할 때 반대측 정상귀의 형태 를 기준으로 하더라도 성인이 되었을 때 차이가 없고 늑연골 의 크기가 이개 뼈대를 제작하기에 충분할 만큼 성장한다는 점을 근거로 한다. ${ }^{\text {) }}$ 하지만 12 세가 될 때까지는 미약하지만 이개의 추가적인 성장이 이루어지고, 어릴수록 흥부 늑연골 의 손상이 더 많다는 의견도 많다. ${ }^{8)}$ 심리적인 측면에서 대부 분의 아동들은 6 세가 되면 자신의 귀 형태에 대한 자각이 있 기 때문에 수술과정에서 놀라울 정도로 잘 협조하지만, 그렇 지 못한 경우에는 인지적 발달이 이루어질 때까지 수술을 늦 추고 환아와의 관계가 확립되도록 노력하는 편이 낫다. ${ }^{9}$

자가 늑연골 채취로 인한 공여부의 손상 위험을 최소화하 고, 이개의 복잡한 3차원 구조를 좀 더 쉽게 구현하기 위해 합성물질의 이식 또한 많이 시도되어 왔다. 코성형에서와 달 리 실리콘 뼈대는 돌출로 인한 합병증의 위험이 너무 높기 때 문에 근래에는 사용되지 않으며, 일부에서는 porous polyethylene(Medpore ${ }^{\circledR}$, Porex Surgical, Inc., Newnan, GA, USA) 을 사용하여 비교적 좋은 결과를 보고하고 있기도 하다. ${ }^{10)}$ 다 만 Medpore ${ }^{\circledR}$ 를 포함한 합성 뼈대의 사용은 장기적으로 면 역거부에 의한 돌출 및 피부괴사의 위험이 상존하므로 이에 대한 주의가 따라야만 한다.

\section{자가 늑연골을 이용한 단계적 이개 재건술}

1971년에 Tanzer ${ }^{11)}$ 에 의해 시작된 단계적 이개 재건술은 처 음에 1) 기존의 이수(lobule) 위치 이동, 2) 연골 뼈대의 조각
과 삽입, 3) 귀 거상, 4) 이주 및 이갑개 재건으로 구성되었다. 1992년에 Brent ${ }^{6}$ 가 600예가 넘는 증례를 정리하여 발표하면 서 Tanzer의 4단계 수술방법을 1) 연골 뼈대의 조각과 삽입, 2) 이수의 위치 이동, 3) 연골 뼈대 거상에 의한 두개-이개각 (cephaloauricular angle) 생성, 4) 이주 및 이갑개 재건의 순으 로 다시 정리하였는데, 여기에서 첫 단계의 순서가 바뀐 이유 는 연골 뼈대를 삽입할 때 반흔 형성에 의한 손상을 받지 않 은 피부를 유지하는 것이 무엇보다도 중요하기 때문이었다. 3 차원적 형태의 이개 연골을 충분히 덮어줄 수 있는 피부조직 을 확보하는 것은 그리 간단한 문제가 아니며 이는 거의 모든 귀성형 수술에서 공통적으로 대면하게 되는 문제로서, 자연 스럽고 적절한 크기의 연골 뼈대를 조각하는 것만큼이나 수 술 후 결과에 큰 영향을 미치게 된다. 피부 절개선을 도안할 때 의 원칙은 이수를 포함하는 잔존 피부가 이식되는 연골 뼈대 의 하부를 덮어줌으로써 환자의 피부가 손상 없이 뼈대의 상부 이륜부를 덮을 수 있도록 하는 것에 있다. 이를 위해 Brent ${ }^{4-6)}$ 는 잔존 이개의 후하방 경계에 선상 절개를 이용하며, Magritz 와 Siegert ${ }^{16)}$ 는 caudal rudiment에 Z-plasty incision을 만드 는 데 비해 $\mathrm{Nagata}^{12)}$ 는 이수의 후방으로부터 양쪽으로 이어 지는 "W" 절개선을 도안하여 연골 뼈대를 덮을 피부를 넓게 확보한다. 어떤 술자는 뼈대를 삽입할 위치의 위쪽으로 temporal hairline 내에서 sinusoidal incision을 가하기도 하는데, 이처럼 뼈대 위치로부터 떨어져서 피부절개를 가하는 것에 는 몇 가지 장점이 있다. 이는 안면부의 반흔 형성을 피할 수 있고 절개부가 연골 뼈대로부터 멀리 떨어지게 할 수 있으며, 필요할 경우 측두-두정 근막 피판을 도안하기에도 용이하다. 또한 쓰고 남은 늑연골을 "banking" 하기에도 좋은 공간을 제공해준다.

피부 절개 후 피하 포켓을 만드는 과정에서는 남아 있는 잔 존 연골을 제거하게 되는데, 이때 이를 덮고 있는 피부에 손 상을 입히지 않도록 주의하여야 하며, 박리 과정에서 천공이 발생하는 경우에는 이를 완전히 봉합하여야만 연골 뼈대의 삽입 후 피부와의 부착이 용이하게 이루어지도록 음압을 제 대로 가할 수 있다. 연골 뼈대를 넣기 위한 피부 포켓을 만드 는 과정에서 박리되는 피부의 두께는 최대한 얇게 유지되어 야만 연골 뼈대의 형태가 제대로 나타나게 되지만, 두께가 지 나치게 얇을 경우에는 피부 괴사에 의한 연골 뼈대의 노출이 발생할 위험이 있으므로 수술 후 3차원 구조에 의한 장력을 견딜 수 있을 만큼의 두께를 유지해주어야 한다.

이개 연골이 거의 형성되지 않은 이수형(lobule-type) 소이 증의 경우 잔존 연골이 뼈대의 삽입에 오히려 방해되고 수술 후 혈행 공급에 문제를 일으킬 수 있으므로 완전히 제거하여 야 하지만, 이갑개형(conchal-type) 소이증에서는 이주와 대 

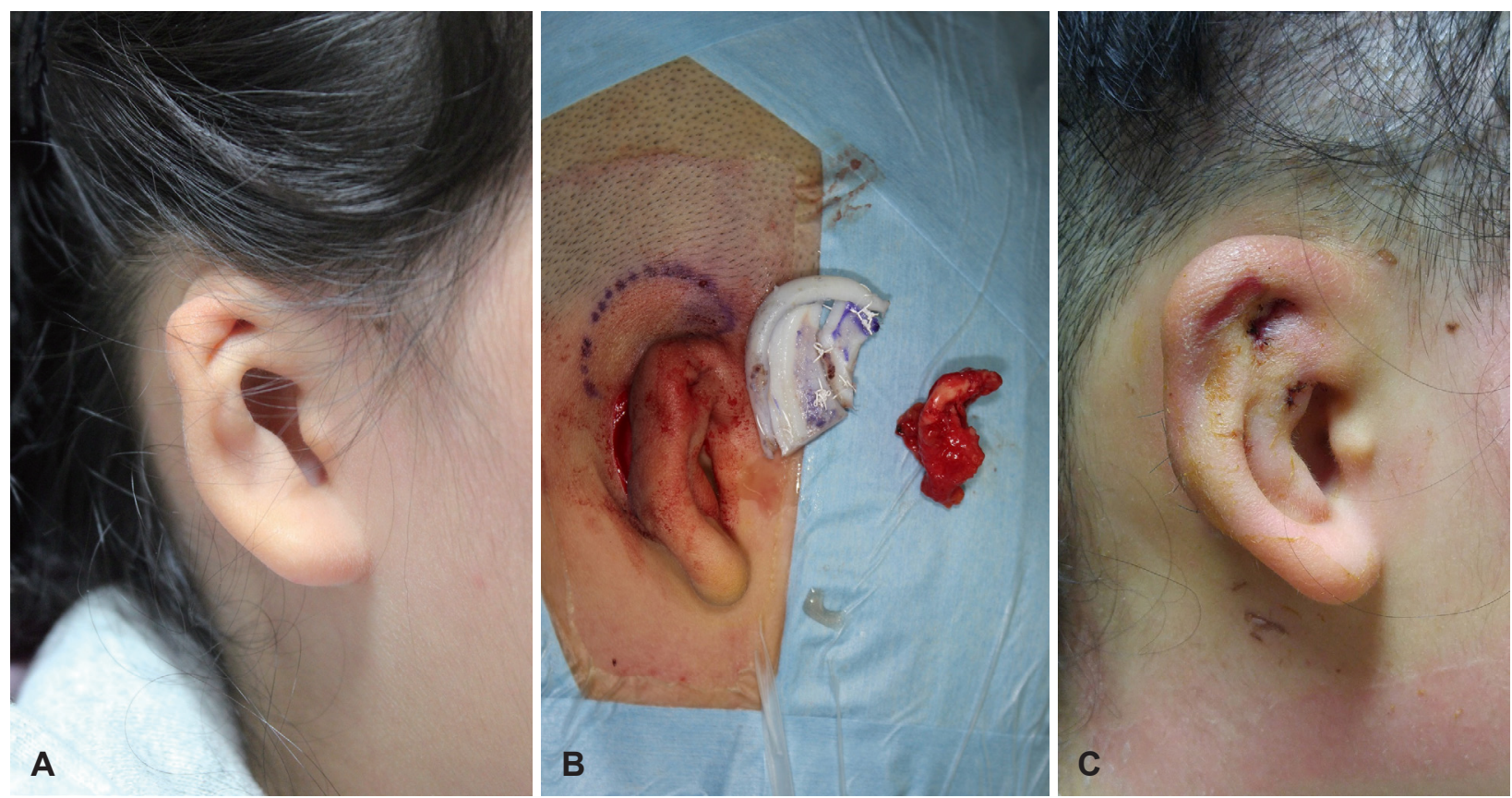

Fig. 1. Reconstruction of helix and antihelix using rib cartilage in a patient with conchal type microtia (A: Preoperative, B: intraoperative, C: postoperative day 5).
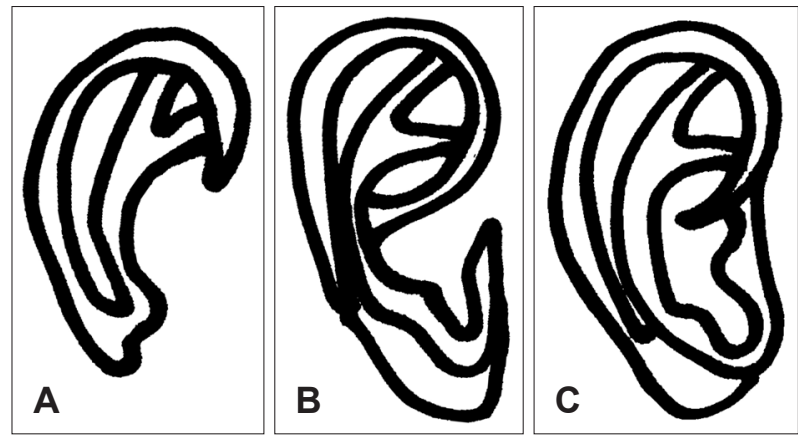

Fig. 2. Illustration of different designs of the cartilage framework (A: Frame designed by Dr. Burt Brent, B: frame designed by Dr. Satoru Nagata, C: frame designed by Dr. Ralph Magritz).

이주, 이갑개 등의 위치와 형태가 보존되어 있는 경우가 있다. 이를 보존하는 것이 미용적으로 적절하다면, 하부 이개를 보 존하고 이륜과 대이륜만을 조각해서 하부 구조의 연골에 이 식하는 것도 가능하다(Fig. 1).

미리 제작된 template에 맞춰 환측 또는 반대측에서 채취 한 늑연골은 “조각”의 과정을 거쳐 이식될 연골 뼈대의 형태 를 갖추게 된다(Fig. 2). Brent ${ }^{4-6)}$ 의 방식에서는 6, 7번 늑연골 편이 함께 부착된 상태로 하나의 절편으로서 대이륜과 대이 주, 그리고 fossa triangularis를 이루는 기저부가 되며, 따로 채취된 길쭉한 8 번 늑연골이 이륜의 형상을 만든다(Figs. $2 \mathrm{~A}$ and 3). 8 번 늑연골은 가늘고 길게 다듬어서 기저부의 가장 자리에 고정시키는데, 이식된 빼대의 3차원 돌출을 더 명확 히 나타낼 수 있도록 입체적으로 기저부에 고정시켜야 하며,

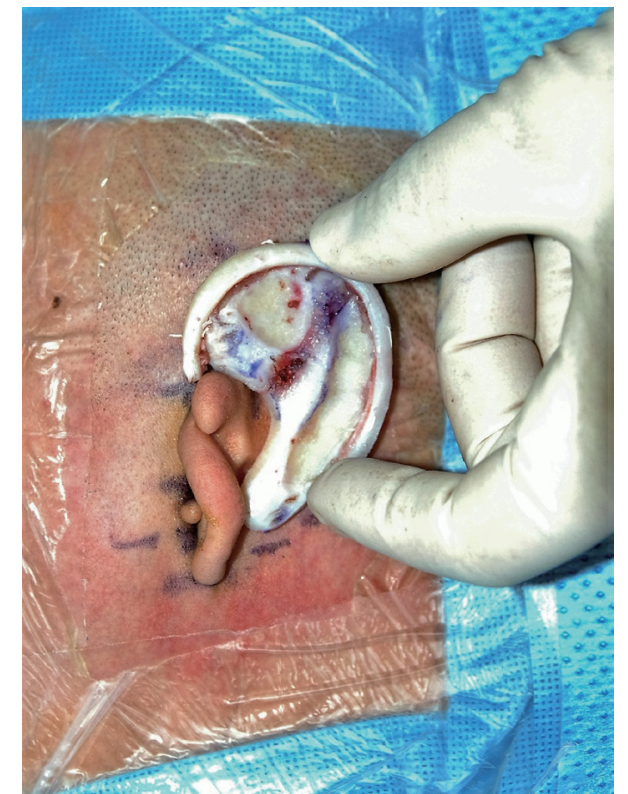

Fig. 3. Reconstruction of lobule type microtia using Brent's technique.

일반적으로 상단부에 비해서 중간부의 돌출이 더 많이 나타 나도록 위치시키는 것이 자연스럽다. 고정을 위한 봉합사로 는 한손으로 뼈대의 위치를 고정시키면서 매듭을 만들기 쉽 고 매듭의 장력을 조절하기 용이한 4-0 스테인리스 스틸 와 이어를 사용하거나 투명한 비흡수성 나일론을 이용한다.

Nagata ${ }^{12,13)}$ 에 의해 정립된 2단계 수술방법에서는 1단계에 서 이수의 위치 이동이 한 번에 이루어지며, 6 9번 늑연골을 
이용하여 4개의 부위로 구성된 연골 빼대를 만들어 삽입한 다(Fig. 2B). ${ }^{12,13)}$ 6 7번 늑연골이 en bloc으로 함께 채취되어 기저부를 이루며, 8번 늑연골이 이륜을 형성하고 9번 늑연골 로는 대이륜을 만든다. 연골 뼈대의 기본 형태를 이루는 기저 부를 조각하여 fossa와 대이륜을 만드는 Brent ${ }^{4-6)}$ 방법과 달 리, 연골편을 이용해 따로 대이륜과 이주를 만들고 이를 기 저부에 봉합하기 때문에 늑연골을 더 크게 채취하여야 하고 피부 절개선 역시 이수 후면으로부터 이갑개를 거쳐 이주의 위치까지 더 길게 이어지게 된다. 이 방법은 대이륜과 이갑개, 이주 및 대이주의 굴곡을 더 명확하게 나타낼 수 있는 장점 이 있지만, 6 9번 늑연골을 한꺼번에 채취하는 데 따른 흥부 합병증의 위험과 이수 및 측두-두정 피판을 이동시킬 때 연 골 뼈대로의 혈행 공급에 문제를 일으킬 가능성이 더 높다 는 점을 주의하여야 한다. ${ }^{13,14}$ Kawanabe와 Nagata ${ }^{15)}$ 는 공여 부의 합병증 위험을 감소시키기 위한 방법으로써 늑연골 채취 시 연골막을 남겨놓고 조각 후에 남은 연골편들을 다시 모아 서 공여부에 재삽입하는 방법을 사용하기도 하였다. Magritz 와 Siegert ${ }^{16)}$ 는 이를 변형시켜 7 9번 늑연골을 채취하여 7 8 번으로부터 기저부를 만들고 9번 늑연골로 이륜을, 대이륜부 는 8 번 늑연골의 남은 부위, 이주-대이주 부위는 7번 늑연골의 남은 연골부에서 조각하는 방법을 사용하였으며(Fig. 2C), 연 골 채취 시 후면의 연골막을 남겨두어 흥부 합병증을 줄이고 자 하였다. ${ }^{16)}$ 완성된 연골 뼈대는 피하 포켓 안으로 아래쪽에 서부터 조심스럽게 돌려 넣고 봉합하지 않은 채 뒤쪽과 안쪽 두 곳에 흡입 배출관을 연결시킨다.

연골 뼈대의 삽입과 이수의 위치 이동이 이루어진 후 다음 단계로 진행되는 술기는 후이개구(retroauricular sulcus)의 생 성이다. 뼈대를 삽입한 후 3 6개월 뒤에 측두면과 같은 각으 로 누워 있는 연골 뼈대를 거상시켜 정상적인 측두-이개각을 만들기 위해서 이륜부 외측으로 절개를 가하는데, 경계부위 보다 수 $\mathrm{mm}$ 바깥쪽으로 도안을 하여 피부가 이륜부를 완전 히 감쌀 수 있도록 한다. 연골 뼈대를 들어올릴 때는 연골이 노출되지 않도록 연부조직이 뼈대를 얇게 감싸고 있는 상태 로 들어올려야만 감염의 위험을 줄이고 피부 이식편의 생착 이 정상적으로 이루어질 수 있다. 이 단계에서는 들어올린 연 골 뼈대와 측두면의 사이에 피하에 저장해두었던 초승달 형 태의 연골편을 이개와 측두면의 사이에 고정시키고, 후면에 피부 이식을 한다. 이렇게 이식된 연골편과 피부의 혈액공급 을 위해서는 혈관성 피판이 사용되는데, Nagata ${ }^{17}$ 가 제안한 측두-두정 근막 피판은 상부의 두피에서 얻어지며 천측두 동 맥(superficial temporal artery)에 의해 혈행 공급을 받는다. 이외에도 Yoshimura ${ }^{18}{ }^{18)}$ 은 유양동 부위로부터 얻어지는 후 이개 근막 피판(retroauricular fascial flap)을 Magritz와 Sieg- $\mathrm{ert}^{16)}$ 는 유양동과 후두부로부터의 superficial muscular aponeurotic system advancement flap을 제안하기도 하였다. 이들 각 피판은 연골편과 피부 이식편의 혈행 공급을 유지하 는 데 기능상의 차이를 보이지는 않는다. ${ }^{19)}$

현재 사용되는 이개 재건술은 많은 술자들에 의해서 기술적 변모를 겪고 있지만 기본적인 개념은 앞서 설명한 Brent와 Nagata에 의한 방법에 근간을 두고 있다. Siegert와 Weerda ${ }^{20)}$ 는 연골편을 덮기 위한 측두-두정 피판 대신 하방 피판을 이 용하고 2단계에 외이도 재건술을 함께 시행하였으며, ${ }^{21)} \mathrm{Park}^{22)}$ 은 피판 구조를 개선하고 3 단계의 재건술을 통해서 좋은 결과 를 보고하였다. ${ }^{23)}$ Firmin $^{24)}$ 은 연골 뼈대를 삽입하기 위한 피 부 절개를 기형의 형태에 따라 3 가지로 분류하고, 연골 뼈대 의 제작 시 이륜과 이주를 가늘게 연결하여 보강함으로써 형 태와 안정성의 보강을 추구하였다. ${ }^{25)}$ 다만 술자에 따라서는 이식부의 손상을 최소화하기 위한 방법으로서 검증된 Brent 의 단계적 수술법을 더 선호하기도 한다. ${ }^{26)}$

\section{이개 재건 수술의 Learning Curve}

소이증의 빈도가 낮고 수술방법이 복잡하기 때문에 이개 재건술에 대한 고도의 술기를 갖추고 있는 술자는 그 수가 많지 않다. 더구나 수술의 결과는 전적으로 미용적 관점에서 만 평가되고 각 단계별 술기를 객관적으로 평가할 방법이 마 땅치 않으므로, 각각의 증례 단위로만 토의와 교육이 이루어 지는 것이 일반적이다. 외이 재건술의 술기에 익숙해지기 위해 서는 실제 수술을 통해서 경험을 쌓기 전에 연골 뼈대를 조각 하는 방법에 대한 많은 실습과 연수를 통해서 경험을 쌓는 것이 필요하다. 실습 재료로서 비누, 감자 등의 야채, 사체 연 골, 치과용 실리콘 등을 활용할 수 있는데, 각각의 장단점이 있지만 실습에 용이하도록 사전에 늑연골 형태로 제작된 실 리콘 모형을 이용하여 연습하는 것이 실제 수술에서 직면하 게 되는 많은 상황에 대한 이해를 도울 수 있다. 충분히 경험 이 쌓이지 않은 상태에서 섣불리 수술을 시행하는 것은 좋지 않은 결과를 만들어내게 되어 환자들의 순응도도 낮아지는 결과를 초래할 뿐 아니라 술자 자신의 자신감도 상실되게 된 다. ${ }^{27)}$ 일단 많은 연습을 통해서 연골 빼대의 조각이 익숙해지 면, 수술 전후의 계획과 template 제작, 연부조직 및 피판의 조작에 대한 부분도 함께 익숙해질 수 있도록 하여야 한다.

\section{결 론}

소이증 및 외이 기형에 대한 수술적 교정은 이비인후과가 아닌 다른 분야 전문의의 손을 통해 이루어지는 경우가 많이 
있었지만, 이는 청력에 대한 배려가 소홀해지고 환자들이 자 신의 귀에 대한 종합적인 관리를 소홀히 하게 되는 결과를 낳아 왔다. 외이 재건의 분야가 이과 영역의 엄연한 한 부분 으로서 잘 발전한다면, 외이 및 외이도의 기형을 가진 환아 들이 귀에 대해 지속적인 치료와 관리를 받을 수 있는 좋은 기회가 되리라 기대한다.

\section{REFERENCES}

1) Oh JH. Cartilage tissue engineering for auricular reconstruction. Korean J Otorhinolaryngol-Head Neck Surg 2011;54(10):667-74.

2) Kelley PE, Scholes MA. Microtia and congenital aural atresia. Otolaryngol Clin North Am 2007;40(1):61-80, vi.

3) Weerda H. Classification of congenital deformities of the auricle. Facial Plast Surg 1988;5(5):385-8.

4) Brent $B$. The correction of microtia with autogenous cartilage grafts: II. Atypical and complex deformities. Plast Reconstr Surg 1980;66 (1):13-21.

5) Bauer BS. Reconstruction of the microtic ear. J Pediatr Surg 1984;19 (4):440-5

6) Brent B. Auricular repair with autogenous rib cartilage grafts: two decades of experience with 600 cases. Plast Reconstr Surg 1992;90 (3):355-74; discussion 375-6.

7) Brent B. Technical advances in ear reconstruction with autogenous rib cartilage grafts: personal experience with 1200 cases. Plast Reconstr Surg 1999;104(2):319-34; discussion 335-8.

8) Beahm EK, Walton RL. Auricular reconstruction for microtia: part I. Anatomy, embryology, and clinical evaluation. Plast Reconstr Surg 2002;109(7):2473-82; quiz following 2482.

9) Quatela VC, Thompson SK, Goldman ND. Microtia reconstruction. Facial Plast Surg Clin North Am 2006;14(2):117-27, vi.

10) Romo T 3rd, Fozo MS, Sclafani AP. Microtia reconstruction using a porous polyethylene framework. Facial Plast Surg 2000;16(1):15-22.

11) Tanzer RC. Total reconstruction of the auricle. The evolution of a plan of treatment. Plast Reconstr Surg 1971;47(6):523-33.

12) Nagata $S$. A new method of total reconstruction of the auricle for microtia. Plast Reconstr Surg 1993;92(2):187-201.

13) Nagata S. Modification of the stages in total reconstruction of the auricle: Part I. Grafting the three-dimensional costal cartilage framework for lobule-type microtia. Plast Reconstr Surg 1994;93(2): 221-30; discussion 267-8.

14) Walton RL, Beahm EK. Auricular reconstruction for microtia: Part II. Surgical techniques. Plast Reconstr Surg 2002;110(1):234-49; quiz 250-1, 387.

15) Kawanabe $Y$, Nagata $S$. A new method of costal cartilage harvest for total auricular reconstruction: part I. Avoidance and prevention of intraoperative and postoperative complications and problems. Plast Reconstr Surg 2006;117(6):2011-8.

16) Magritz R, Siegert R. Auricular reconstruction: surgical innovations, training methods, and an attempt for a look forward. Facial Plast Surg 2014;30(2):183-93.

17) Nagata S. Secondary reconstruction for unfavorable microtia results utilizing temporoparietal and innominate fascia flaps. Plast Reconstr Surg 1994;94(2):254-65; discussion 266-7.

18) Yoshimura $K$, Asato $H$, Nakatsuka $T$, Sugawara $Y$, Park S. Elevation of a constructed auricle using the anteriorly based mastoid fascial flap. Br J Plast Surg 1999;52(7):530-3.

19) Duvdevani SI, Magritz R, Siegert R. Sulcus construction in microtia repair: a retrospective comparison of different techniques. JAMA Facial Plast Surg 2013;15(1):17-20.

20) Siegert R, Weerda H. Two-step external ear canal construction in atresia as part of auricular reconstruction. Laryngoscope 2001;111(4 Pt 1):708-14.

21) Siegert R. Combined reconstruction of congenital auricular atresia and severe microtia. Adv Otorhinolaryngol 2010;68:95-107.

22) Park C. Modification of two-flap method and framework construction for reconstruction of atypical congenital auricular deformities. Plast Reconstr Surg 1997;99(7):1846-57.

23) Park C, Lee TJ, Shin KS, Kim YW. A single-stage two-flap method of total ear reconstruction. Plast Reconstr Surg 1991;88(3):404-12.

24) Firmin F. State-of-the-art autogenous ear reconstruction in cases of microtia. Adv Otorhinolaryngol 2010;68:25-52.

25) Firmin F, Marchac A. A novel algorithm for autologous ear reconstruction. Semin Plast Surg 2011;25(4):257-64.

26) Park C, Yoo YS, Hong ST. An update on auricular reconstruction: three major auricular malformations of microtia, prominent ear and cryptotia. Curr Opin Otolaryngol Head Neck Surg 2010;18(6):544-9.

27) Wilkes GH. Learning to perform ear reconstruction. Facial Plast Surg 2009;25(3):158-63.

\section{정답 및 해설}

답 비인강 결핵(nasopharyngeal tuberculosis)

해 설 Reference: 이비인후과학 두경부외과학회. 서울: 일조각;2009. p.424-5.

Lee CJ, Choi YH, Jeon ES, Lee DH. Six cases of nasal cavity and nasopharyngeal tuberculosis. Korean J Otorhinolaryngol-Head Neck Surg 2013;56(12):795-9.

임상적으로는 결핵성 중이염을 동반한 비인강 결핵 소견이며, 조직검사에서 만성 육아종성 염증(chronic granulomatous inflammation) 및 건락성 괴사(caseous necrosis) 소견을 보였으며, Tb-PCR 검사 양성 소견으로 비인강 결핵으로 진단 하였다. 6 개월 이상 항결핵요법이 주된 치료법이다. 